\title{
THE PERCEPTIONS OF JAPANESE TOURISTS TOWARDS THE JAPANESE GUIDES IN BALI
}

\author{
Lukia Zuraida \\ Language Centre, STPNB JI. Dharmawangsa, Kampial, Nusa Dua. \\ Bali, Indonesia \\ lukiazuraida@gmail.com \\ Indah Kusumarini \\ Language Centre, STPNB JI. Dharmawangsa, Kampial, Nusa Dua. \\ Bali, Indonesia \\ indahnusabakti@gmail.com
}

\begin{abstract}
The research aims at knowing and analyzing the perceptions of Japanese tourists towards the Japanese guides in Bali.. Japanese guides have important role in tourism in providing services to the Japanese guests. Explorations factor analysis used to measure quality service of the guide. Variable of research used 5 dimensions of quality service from Zeithaml-Parasuraman- Berry. These are tangible, reliability, responsiveness, assurance, and empathy. The data were collected by using questioners administered to 100 Japanese tourists, interview and document study. The data analyzed quantitatively based on scale of Likert. Character of respondents was categorized based on sex, age, occupancy, length of stay, and visit purpose. The findings of this study are "empathy" has biggest point from 4 others. "Responsiveness", "assurance", "reliability" in no 2, 3, and 4. "Tangible" got the lowest point from that 5 dimensions. "Tangible" aspect need to be followed up by giving serious attention and action to increase quality of service for Japanese guest in Bali.
\end{abstract}

Key words : Japanese guide, service quality, 5 dimensions of quality, factor analysis.

\section{INTRODUCTION}

The visit of Japanese tourists to Bali since the 90s has always occupied the top ranking list of Top Ten house visits. Bali historically is one of the favorite tourist destinations in Japan. But since year 2000 Japanese tourists have been decreasing. Bomb Bali teror on 2002 and 2005 significanly brought deep impact to tourism in Bali. Since then Japanese visit to Bali can not be the same like 1990. In 2010 tsunami hit Japan and this disaster directly affected to Japanese visited to Bali. Post-tsunami, Japanese visitors was decreased (5, $64 \%$ ). At the end of 2011, decreased about 183,284 (25,63\%), Year 2012 decreased 191,816. By 2013, the condition began to recover again, Japanese visitors increased by 8.49\% (208.115). In 2014 rising $14.78 \%$ ( 3.41 million), exceeding the targeted number (2.9 million). In the beginning of 2015 , the number was rising up to $25 \%$.

It's been recognized that Japanese tourists are very sensitive with issues of security. Travel warning issued by the Japanese Government will have a direct impact on Japanese tourist visits to Bali. But after banned were lifted, they will come back to Bali. Bali seems to become a tourist icon option for the citizens of Japan. This potential situation must be preserved, in order to Japanese visitors to Bali can always be maintained.

Japanese guides have important role in tourism in providing services to the Japanese guests. Bali tour guides already meet the criteria of the competent tour guide? Few complaints ever delivered by Japanese tourists regarding the service of tour guide. Because of 
lack understanding, the guide escorted Japanese tourists to see the funeral ceremony (ngaben) which is corpse burning. Japanese feel uncomfortable seeing the corpse was burned directly. Guide should clarify in advance to guests before escorting them. The other case is experienced by one of JTB's guide. Guest complained because the guide delivered them to art shops. They think that it is a guide's will. Instead of shopping to art shops is part of the agenda in the itinerary. According to the Coordinator of the JTB Japan Travel guide, there are also problems associated with attitude of the guide. Guests feel like that the guide being too familiar. For Japanese, stance when running tasks of the profession cannot be equated with an attitude as a person who is already familiar.

Regarding some of the cases above, research has to be conducted towards to find out the opinion of the Japanese tourists to the service quality of Japanese guides in Bali. Based on the explanation on the background of the above issue, then that becomes the principal problem is: "How (good) the quality service of Japanese guide towards Japanese guests in Bali? ". The goal of this research activity is to know the service quality of Japanese guide towards Japanese tourists in Bali.

\section{METHOD}

Tour guide is someone who provides guidance, information and instructions about tourism as well as help everything needed by the tourists. The tour guide is special profession provide explanations, instructions and guides to the tourists who are travelling. Suyitno (2005:1) explains that the tour guide is a person who accompanies; provide information and guidance and advice to travelers in its activities. A tour guide is someone who provides explanations and instructions to tourists of everything the tourists are going to see and be seen when they visit to a tourist attraction. The tour guide duties are :1) Help take care of the luggage of travelers, 2) to arrange tourists traveling with transportation available, and 3) Provide an explanations of the itinerary and travel documents, places of interest, accommodation, transportation and other tourist facilities.

The American marketing Association in Supranto (2006:227) defines service as a separate section which can be identified, it is a major intangible activities which give satisfaction and not necessarily tied to the sale of an item. To perform services can be done with or without the need for tangible goods.

Zeithaml and Bitner in Lupiyoadi, Hamdani (2006:5) give limitation in service, "Service is all economic activities whose output is not physical product or construction is generally consumed at the same time it is produced and provides added value in forms (such as convenience, amusement, comfort or health)". Service are economics activities and the result is not a physical product or a-shaped construction that are commonly produced and consumed simultaneously and provide added value (e.g., convenience, entertainment, leisure and health). From the various definitions above can be inferred that the service is the main activity which is not physical shape (intangible) from producers to consumers that gives satisfaction to the consumer. The service did not give ownership.

The definition of the quality according to the Poerwadarminta in the General Dictionary Indonesian Language (1982:545): the quality is a good or bad of an object or the State of an object. Quality is the state of an item or service is in a state of truth. According to Christopher in Arif (2006:131) a product when it is coupled with the service will generate a power that benefits the company raise profit even to face competition. According to Zeithaml in Rangkuti (2003:21) there are two main factors that affect the quality of service, there are expected of service and perceived service. If the service accepted (perceived service) as expected then the service quality perceived good and satisfying. 
If the services are beyond customer expectations, they are perceived as ideal quality. Conversely, if the services accepted lesser than expected, then the quality of service perceived bad. Thus whether good or bad of quality service depend on the ability of service providers to meet the expectations of its customers consistently.

The dimension of service quality according to Zeithaml - Parasuraman-Berry in Arif (2006:135) explains the five dimensions of service quality which is outlined as follows:
a. Tangible
b. Reliability
c. Responsiveness
d. Assurance
e. Empathy

The principles according to Walkins in Tjiptono (1996:75) there are 6 principles of quality service which are very useful in the consummation to quality, i.e. : 1) Leadership, 2) Education, 3) Plan, 3) Review, 4) Communication, 5). Reward and recognition ( total human reward).

This research is descriptive research using quantitative analysis of factors. The variable will be grouped into similar groups. Variables created one or more batches of new variables that are less than the amount of the initial variables. The new group of variables is known by as a factor. This research used the Exploratory Factor Analysis i.e. summarizes the variables into one group of new variables/factors.

Research variables based on five dimensions of service quality expressed by Zeithaml-Parasuraman-Berry in the Arif (2006:135):

1. Tangible. i.e. : outlook (grooming)

2. Reliability. i.e.: skills in communicating with guests, a reliable guide to take guests on a trip.

3. Responsiveness. i.e.: responsiveness in meeting the demand for immediate response, response if the guests sick or in trouble.

4. Assurance, i.e.: make guests feel comfortable while in traveling, sight-seeing or seeing attractions.

5. Empathy, i.e. : Guide does not discriminate the treatment and attention given to guests in a friendly and sincere.

For measuring five dimensions of service quality will be given a value of 5 likert scale i.e. "excellent" given the value of 5 , "good" given the value 4 , "quite good" given the value of 3 , "less good" given the value of 2 , "not good" is given a value of 1 .

The instrument used in this study is a set of questionnaires that contains 5 dimensions of service, and each variable is divided into some questions. Those questions are delivered to capture information from Japanese guests who have completed visits in Bali. The location of taking the sample was at the International Departure Ngurah Rai Airport, Bali. In this study Cronbach Alpha coefficient used to verifying reliability. If the value $\geq 0.6$ of Cronbach Alpha then the instruments used are declared reliable. The results obtained by calculation of Cronbach Alpha coefficient was 0.954 . This value is greater than 0.6. It is shows that the measurements can provide consistent results when carried out remeasurement on the same subject.

To obtain the sample used the non probability sampling method (samples are not random). This sampling technique does not give equal opportunity for each element or member of a population to be selected into the sample. Accidental sampling techniques used to select the samples. That is anyone who happened to be found and entered in the category of population can be included as a sample and the respondents. (Burhan Bungin, 2011:126). 
Slovin formula used to determine the number of sample (Sedarmayanti and Syarifudin (2002:143)):

Description:

$$
\mathrm{n}=\frac{\mathrm{N}}{1+\mathrm{N}(\mathrm{e})^{2}}
$$

$\mathrm{n}=$ The sample size

$\mathrm{N}=$ The population (the average number of Japanese tourists last

5 years) $e=10 \%$ allowances used in this study

From the calculation with the formula above, the total sample set for 100 people respondents.

\section{THE RESULTS}

\section{Data Analysis Techniques}

Collected data which consists of 28 variables grouped into several factors with the SPSS program version 15:00. After that will be analyzed with the theory of service quality from Pasuraman "The Five Dimensions Of Service Quality" i.e.: tangible, reliability, responsiveness, assurance and empathy.

The characters of the respondents are differentiated according to gender, age, occupation, length of stay, destinations to Bali. According to gender, a respondent in this study consists of 32 $\%$ of male and $68 \%$ female from 100 respondents. For the age aspect, most respondents are in the productive age (20 to 40 th) i.e. $56 \%$. The elderly have also founded a big percentage up to $35 \%$. This reflected that many elderly segment also traveling to Bali. Sufficient financial factor and they have savings/retirement money and free time, making them easy to travel. The age of the elderly appear to be noteworthy because it is a potential segment. Majority of the respondents are employees of the private sector that is as much as $72 \%$. Most of visit purpose is for tour/traveling. Length of stay is about 4 - 5 nights or 1 week. First coming guest to Bali is $75 \%$, and $25 \%$ has been visiting Bali before (repeated guest).

\section{The Correlation Matrix}

In this study used exploratory factor analysis that summarizes the variables into one group of new variables/factors. Factor analysis is done with the following steps:

1. Determining indicators/variables

28 indicators/variables will be measured to know the quality of Japanese guide service.

2. Creating the correlation matrix

To known the relationships between 28 variables was used the results of processing data through SPSS version 15.00. Variables that are not interconnected with other variables are excluded from the analysis.

To know that between the variables are related or not, needs to be seen:

1) Value of Determinant of Correlation Matrix approaching 0 point.

2) Value scale of Bartlett Test of Spherical with Significance smaller than $<0,05$

3) Value of Keyser-Meyer-Olkim (KMO) > 0,5

4) Value of Measure of Sampling Adequacy (MSA) >0.5.

From the results of the analysis of the variable quality of Japanese guide service, then retrieved:

1) Value of Determinant of Correlation Matrix approaching 0 point. It shows that the identified variables are related or correlated.

2) Value scale of Bartlett's Test of Sphericty with Significance showed value of 2.163,29. It is explained that the relationships between these variables was significant. 
3) Value of Keyser-Meyer-Olkim (KMO) was 0,896, it showed that the adequacy of the sample used in this study is already feasible because $>0.5$.

4) Value of Measure of Sampling Adequacy (MSA) > 0.5 .

\section{Numbers of factors}

The number of factors is determined from the value of the Eigen value. Bigger Eigen value of factors can show the better in representing a number of variables. Factor with the bigger Eigen value or equal to 1 (one), was selected.

An explanation of each of these factors is as follows:

1. Factor I (empathy)

This factor has Eigen value of 13.14 and 46.93 percent variance.

2. Factor II (responsiveness)

This factor has Eigen value of 2.29 and has variance amounting to 8.2 percent

3. Factor III

This factor has Eigen value of 1.7 and 86.08 percent variance.

4. Factor IV

This factor has Eigen value of 1,26 and has variance amounting to 4.5 percent

5. Factor $\mathrm{V}$

This factor has Eigen value of 3.59 and has variance amounting to 1.01 percent

\section{CONCLUSION AND SUGGESTION}

Referring to theory of the five dimensions of service quality, the empathy gained highest valuation from the respondents. It means the guide provided attention, have the sensitivity and can even be friendly with guests. The second order is the dimension of responsiveness, the 3rd is assurance, reliability is the 4th and 5th is tangible.

"Responsiveness" reflects that the guide in Bali, deftly response to the guest needs, able to handle guest complaints, and has the will to help. The dimension of "assurance" got an average assessment. The ability guide in maintaining on time when running the task, take care of guests luggage got average valuation.

While the "reliability" and "tangible" got dissatisfactory valuation from the respondents. Less proficient of Japanese language, less ability to explain the sights, tours, new attractions and provide professional service. The last order was tangible dimension. This dimension got the lowest valuation, such as the appearance of the guide was not neatly, no name card, untidy uniform, etc.

From the results of a factor analysis showed that the dimension of "empathy" gets the highest appraisal from respondents. Japanese guide in Bali is able to provide attention, have the sensitivity and can even be friendly with guests.

From the result of this research, we give suggestion as follow:

1. Empathy and responsive attitude continues to be maintained and improved.

2. Tangible dimension got the lowest valuation. Improvements need to be made in these elements, such as training, improving good appearance, attractive and cleanliness.

3. Further research need to be done in order to find roots problems related to tangible dimension, so it will be found a solution to this problem.

4. Required cooperation between the stake holders of tourism, such as travel agents, tourism and local governments in improving the appearance of the tour guide in Bali. 


\section{REFERENCES}

Arief, Mts.2005. Pemasaran Jasa Dan Kualitas Pelayanan : Bagaimana Mengelola Kualitas Pelayanan Agar memuaskan Tamu. Malang: Bayumedia Publishing

Bungin, Burhan. 2011. Metodologi Penellitian Kuantitatif, Komunikasi, Ekonomi, dan Kebijakan Publik serta IImu Sosial lainnya.Jakarta : Kencana Prenada Media Danapriatna, N.2005. Pengantar Statistika. Yogyakarta : Graha IImu

Poerwadarminta WJS. 2003. Kamus Besar Bahasa Indonesia. Jakarta: Balai Pustaka Rambat, L dan Hamdani, A. 2006. Manajemen Pemasaran Jasa. Jakarta : PT Salemba Empat Riduwan.2010. Dasar Dasar Statistik, Cet 4. Bandung : Alfabeta Sedarmayanti dan Syarifudin, H. 2011. Metodologi Penelitian. Bandung: Mandar Maju Supranto. 2006. Pengukuran Tingkat Kepuasan Pelanggan . Jakarta:Rineka Cipta Suyitno. 2005. Pemanduan Wisata Tour Guiding. Yogyakarta : Graha Ilmu Tjiptono, Fandy. 1996. Manajemen Jasa.Yogyakarta : Andi Offset Yoeti, Oka A. 2011. Tour and Travel Management. Jakarta : Pradnya Paramita www.disparda.baliprov.go.id/id/Statistik . Jumlah kunjungan wisatawan mancanegara ke Bali. Statistik Dinas pariwisata Bali www.statistikian.com/2014/03/analisis-faktor.html

Zeithaml, Valerie. Bitner, Mary Jo. 2000. Service Marketing ; Integrating Customer Focus Across the Firm. Jakarta : PT Index 